\title{
Proses Berpikir Siswa dalam Menyelesaikan Soal Higher Order Thinking Skills Berdasarkan Pemahaman Konseptual dan Prosedural
}

\author{
Puji Astuti ${ }^{1}$, Abdul Qohar ${ }^{2}$, Erry Hidayanto ${ }^{2}$ \\ ${ }^{1}$ Pendidikan Dasar-Universitas Negeri Malang \\ ${ }^{2}$ Pendidikan Matematika-Universitas Negeri Malang
}

\begin{tabular}{l}
\hline \hline INFO ARTIKEL \\
\hline Riwayat Artikel: \\
Diterima: $13-12-2018$ \\
Disetujui: $26-01-2019$ \\
\hline
\end{tabular}

\section{Kata kunci:}

thought process; higher order thinking skills questions;

conceptual understanding; procedural understanding proses berpikir; soal higher order thinking skills; pemahaman konseptual; pemahaman prosedural

\begin{abstract}
ABSTRAK
Abstract: This study aims to describe the thinking process of students in solving Higher Order Thinking Skills problems based on conceptual and procedural understanding. This type of research is descriptive research. The subject of this study was the eighth-grade students of Ma'arif 3 Islamic Middle School Malang. The results of the study were obtained (1) Based on the conceptual understanding of the subject did not meet the indicators presenting concepts in various forms of mathematics, but fulfilling the indicators rewrite the concepts that had been studied and could apply the concepts algorithmically. (2) Based on procedural understanding the subject meets the indicators of choosing the right procedure in solving the problem, but it is not appropriate to know when and how to use the procedure and apply the procedure chosen to solve the problem.
\end{abstract}

\begin{abstract}
Abstrak: Penelitian ini bertujuan untuk mendeskripsikan proses berpikir siswa dalam menyelesaikan soal Higher Order Thinking Skills berdasarkan pemahaman konseptual dan prosedural. Jenis penelitian ini adalah penelitian deskriptif. Subjek penelitian ini adalah siswa kelas VIII SMP Islam Ma'arif 3 Malang. Hasil penelitian diperoleh (1) berdasarkan pemahaman konseptual subjek belum memenuhi indikator mempresentasikan konsep dalam berbagai bentuk matematika, tetapi memenuhi indikator menuliskan kembali konsep yang telah dipelajari dan dapat menerapkan konsep secara algoritma; (2) berdasarkan pemahaman prosedural subjek memenuhi indikator memilih prosedur yang tepat dalam menyelesaikan masalah, namun kurang tepat dalam mengetahui kapan dan bagaimana menggunakan prosedur tersebut dan mengaplikasikan prosedur yang dipilih untuk memecahkan masalah.
\end{abstract}

\author{
Alamat Korespondensi: \\ Puji Astuti \\ Pendidikan Dasar \\ Universitas Negeri Malang \\ Jalan Semarang 5 Malang \\ E-mail: pujiastuti2695@gmail.com
}

Higher Order Thinking Skills merupakan kemampuan berpikir yang harus dimiliki oleh setiap peserta didik dalam menyelesaikan masalah matematika. Menurut (Smith, 2014) Higher Order Thinking Skills terjadi ketika adanya penggabungan antara informasi lama dengan informasi baru yang digunakan untuk menyelesaikan masalah. Dari definisi di atas banyak kegiatan yang dapat dilakukan dengan Higher Order Thinking Skills, yaitu (1) menentukan sesuatu; (2) melakukan sesuatu penyelesaian; (3) memuat sesuatu objek yang baru; (4) membuat prediksi; (5) memecahkan masalah tidak rutin. Dalam melakukan kegiatan Higher Order Thinking Skills siswa harus menggunakan pemikiran yang lengkap, nonalgoritmic dalam memecahkan masalah, menggunakan strategi penyelesaian yang berbeda (Thompson, 2008).

Menurut (Saido, Siraj, Nordin, \& Amedy, 2015) konsep Higher Order Thinking Skills berasal dari Taksonomi Bloom domain kognitif. Higher Order Thinking Skills berada pada urutan yang lebih tinggi dalam Taksonomi Bloom yaitu menganalisis, mengevaluasi, mencipta, dan membutuhkan penguasaan tingkat sebelumnya (Teimourtash \& Moghaddam, 2017). Dalam penelitian ini indikator soal Higher Order Thinking Skills yang digunakan mengacu pada Taksonomi Bloom revisi yaitu menganalisis, mengevaluasi, dan mencipta. hal ini dipertegas oleh (Krathwohl, 2002) indikator untuk Higher Order Thinking Skills, meliputi menganalisis, mengevaluasi, dan mencipta. Untuk melatih proses berpikir siswa diperlukan suatu cara, salah satunya yaitu dengan memberikan latihan soal sehingga siswa dapat meningkatkan kemampuan yang dimilikinya. Latihan soal yang diberikan dapat berupa pemberian soal Higher Order Thinking Skills. Soal Higher Order Thinking Skills yaitu pertanyaan matematika pada tingkat aplikasi nonrutin dan memuat komponen Higher Order Thinking Skills (Bakar, 2015). Menurut (Ayuningtyas \& Rahaju, 2009) soal yang melibatkan Higher Order Thinking Skills cenderung kompleks dan memiliki banyak solusi. 
Soal kompleks dapat berupa soal pemecahan masalah dimana siswa akan tertantang untuk mencari jawabannya. Soal pemecahan masalah tidak dapat dijawab dengan rutin, tetapi perlu kerja keras untuk mencari jawabannya (Winarni, Setyo, \& Harmini, 2016), sedangkan soal yang memiliki banyak solusi berupa soal terbuka. Soal terbuka memiliki beberapa jawaban benar dan memiliki banyak solusi untuk mendapatkan jawabannya (Sa'dijah, Qohar, \& Anwar, 2017). Dalam penelitian ini permasalahan yang digunakan berupa soal pemecahan masalah. Materi soal yang diberikan yaitu aritmatika sosial.

Berdasarkan penelitian yang dilakukan oleh (Saido, Siraj, Nordin, \& Amedy, 2015) tidak biasa. Salah satu cara untuk meningkatkan Higher Order Thinking Skills siswa yaitu dengan memberikan masalah matematika berupa latihan soal yang berbeda dari contoh. Dari penelitian yang dilakukan oleh (Ayuningtyas \& Rahaju, 2009) diperoleh siswa tidak mampu dalam menyelesaikan soal Higher Order Thinking Skills. Banyak faktor yang menyebabkannya, salah satunya siswa tidak terbiasa dengan soal Higher Order Thinking Skills. Kelemahan dari penelitian (Ayuningtyas \& Rahaju, 2009) adalah soal Higher Order Thinking Skills yang diberikan terlalu banyak. Hal ini disebabkan karena peneliti membuat soal berdasarkan setiap satu indikator mencakup Higher Order Thinking Skills. Indikator Higher Order Thinking Skills yang digunakan dalam penelitian ada delapan sehingga ada delapan soal Higher Order Thinking Skills.

Dalam menyelesaikan soal Higher Order Thinking Skills siswa harus memahami terlebih dahulu apa yang terdapat dalam soal. Agar siswa memperoleh pemahaman mendalam diperlukan pemahaman konseptual dan prosedural. Pemahaman konseptual merupakan bagian dari jaringan yang terdiri masing-masing potongan informasi dan hubungan antara potongan informasi (Masingila, 2009). Dengan pemahaman konseptual diperlukan sebagai dasar menghubungkan antara potonganpotongan informasi. Pengetahuan konseptual diperlukan untuk memahami masalah dan menghasilkan strategi baru atau menyesuaikan strategi yang dikenal untuk memecahkan masalah asli (Tanujaya, Mumu, \& Margono, 2017).

Menurut (Siregar, 2017) memahami matematika bukan hanya pengetahuan tentang konsep yang tidak berhubungan, tetapi juga kemampuan untuk menjelaskan hubungan di antara mereka. Dengan demikian, siswa dengan pemahaman konseptual dapat mengatur pengetahuan mereka dan menjelaskannya sebagai sistem yang koheren. Dari beberapa definisi mengenai pemahaman konseptual di atas, maka peneliti mengambil indikator pemahaman konseptual yang diadaptasi dari (Claudia, 2017), yaitu (1) menuliskan konsep yang telah dipelajari; (2) menerapkan konsep secara terstruktur; (3) mempresentasikan konsep.

Pemaham prosedural adalah suatu prosedur yang familiar atau langkah-langkah untuk menyusun simbol yang diterima (Star, 2016). Menurut (Laswadi, Kusumah, Darwis, Afgani, 2016) pengetahuan tentang prosedur mengacu pada pengetahuan tentang asal-usulnya, algoritma, dan kegunaan. Siswa dengan pemahaman konseptual tidak hanya mengetahui tentang prosedur, tetapi juga mengetahui bagaimana menerapkan prosedur untuk memecahkan masalah. Menurut Walle (2008) pemahaman prosedural merupakan aturan dalam menyelesaikan masalah matematika. Dari definisi beberapa ahli dapat disimpulkan pemahaman prosedural merupakan kemampuan siswa dalam melakukan perhitungan. Adapun indikator dalam pemahaman prosedural yang digunakan diadaptasi dari (Claudia, 2017) yaitu (1) memilih prosedur yang tepat dalam menyelesaikan masalah; (2) mengetahui kapan dan bagaimana prosedur diterapkan; (3) menerapkan prosedur yang telah direncanakan.

Ditinjau dari penelitian terdahulu terkait pemahaman konseptual dan prosedural yang dilakukan oleh (Haghverdi \& Wiest, 2016) diketahui bahwa dalam menyelesaikan masalah diperlukan konsep yang membuat hubungan semantik di antara masalah utama dan elemen yang lebih eksplisit, misalnya menuliskan kumpulan informasi yang ada dalam masalah serta transparan, misalnya menambahkan atau menata ulang masalah yang diberikan secara kontekstual, konseptual dan gabungan kontekstual/konseptual untuk mengurangi kesalahan peserta didik menyelesaikan masalah.

Berdasarkan hasil penelitian yang dilakukan oleh Masingila (2009) diketahui bahwa untuk melihat pemahaman konseptual dan prosedural siswa dapat diketahui melalui tulisan (jawaban) siswa. Dengan melihat tulisan siswa, kita dapat mengetahui seberapa paham siswa dengan materi yang telah diajarkan. Pemahaman konseptual dan prosedural sangat mempengaruhi siswa dalam menyelesaikan soal Higher Order Thinking Skills. Salah satu dari pemahaman tersebut harus ada, agar pemahaman siswa akan soal dapat terlihat. Adapun yang menjadi kekurangan dari penelitian yang telah dilakukan, yaitu (1) dalam melihat pemahaman konseptual dan pemahaman prosedural prosedural hanya dari jawaban siswa mengerjakan soal Higher Order Thinking Skills secara tertulis saja, tidak dari jawaban siswa secara langsung (wawancara), sehingga penelitian yang dilakukan lebih berfokus pada penyelesaian soal; (2) hanya menilai pemahaman konseptual dan prosedural dari tulisan siswa.

\section{METODE}

Jenis penelitian ini adalah penelitian deskriptif kualitatif. Creswell (2010) menyatakan bahwa penelitian kualitatif adalah metode penelitian yang digunakan untuk mengeksplorasi dan memahami makna dari sejumlah individu atau kelompok. Penelitian ini dilakukan untuk mendeskripsikan proses berpikir siswa dalam menyelesaikan soal-soal Higher Order Thinking Skills berdasarkan pemahaman konseptual dan prosedural siswa kelas VIII SMP Islam Ma'arif 3 Malang. Subjek dalam penelitian ini adalah satu orang siswa yang memiliki Higher Order Thinking Skills. 
Pengumpulan data dalam penelitian ini menggunakan teknik tes dan wawancara. Siswa diminta mengerjakan soal Higher Order Thinking Skills, selanjutnya siswa diwawancarai berdasarkan hasil pekerjaannya. Wawancara dilakukan untuk mengonfirmasi hasil tes yang mereka kerjakan. Dalam menganalisis data peneliti mengacu pada Miles dan Hubermen yaitu memilah data, mempresentasikan, dan menarik generalisasi. Instrumen soal yang digunakan berupa satu soal Higher Order Thinking Skills yang telah divalidasi oleh ahli terlebih dahulu. Adapun instrumen soal yang diberikan sebagaimana ditunjukkan pada Gambar 1.

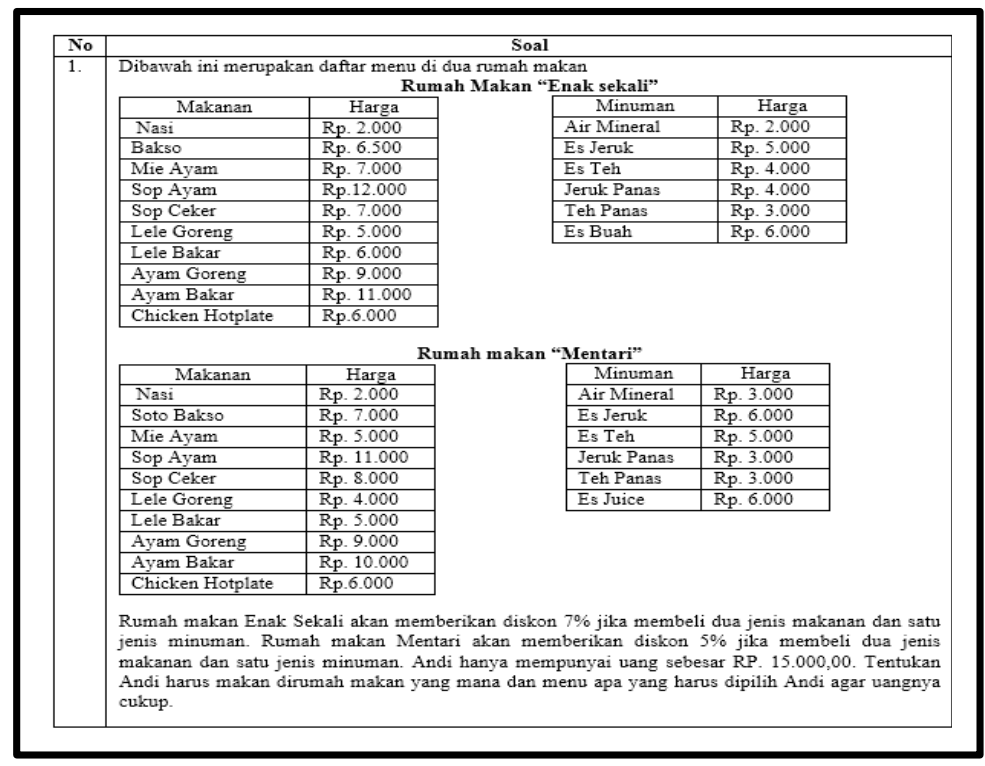

Gambar 1. Instrumen Soal

\section{HASIL}

Berdasarkan hasil tes soal Higher Order Thinking Skills dan wawancara diperoleh bahwa proses berpikir siswa berdasarkan pemahaman konseptual berupa menuliskan konsep yang telah dipelajari. Penulisan konsep dilakukan dengan benar dan sistematis, seperti ditunjukkan pada Gambar 2.

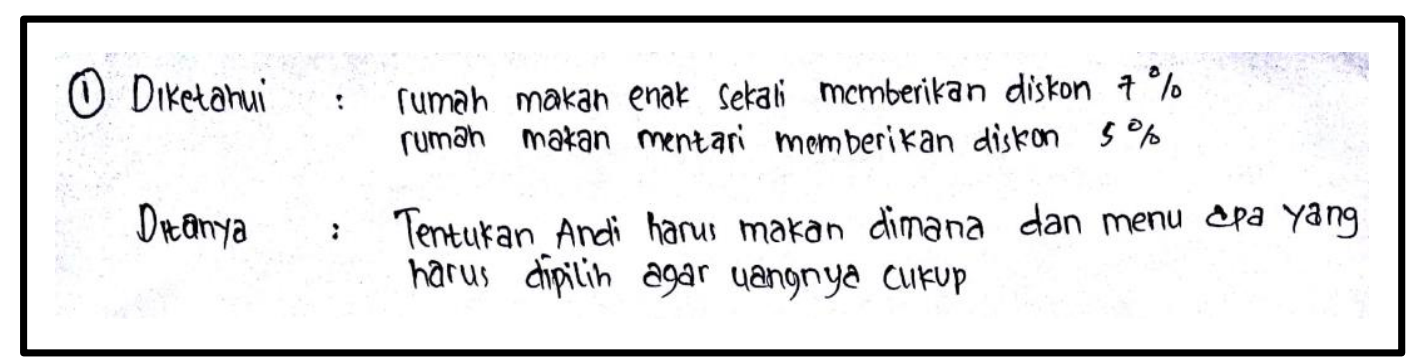

Gambar. 2 Jawaban subjek menuliskan kembali konsep yang telah dipelajari

Dari gambar 2 terlihat subjek telah memenuhi indikator pertama pemahaman konseptual. Subjek telah memahami soal, mengetahui apa yang diminta soal, dan kemudian menggunakan konsep persen dalam menyelesaikan soal. Semua jawaban subjek ditulis secara sistematis dan rapi sehingga memudahkan peneliti saat memeriksa dan menganalisis jawaban siswa. Ketika menuliskan diketahui, subjek menuliskan diskon yang dibagikan oleh masing-masing rumah makan bukan menuliskan harga makanan dan minuman seperti yang tertera pada soal. Untuk mengetahui alasan mengapa subjek menuliskan seperti itu peneliti melakukan wawancara kepada siswa. Adapun kutipan wawancara tersebut adalah sebagai berikut:

$P$ : Kenapa kamu menuliskan seperti itu?

$S:$ Karena itu yang diketahui dari soal

$P$ : Mengapa kamu tidak menuliskan harga makanan dan minuman yang ada dalam tabel seperti dalam soal?

$S$ : Terlalu panjang dan itu telah ada dalam soal 
Dari kutipan wawancara di atas, diketahui bahwa harga makanan dan minuman yang ada dalam tabel pada soal hanya merupakan informasi dari soal tersebut. Sehingga subjek tidak perlu menuliskannya. Dari jawaban subjek terlihat subjek menuliskan diketahui dan ditanya secara baik. Subjek telah mampu memahami maksud soal dengan baik. Siswa dapat menerapkan konsep secara algoritma, subjek telah menuliskan algoritmanya. Hal ini ditunjukkan seperti pada Gambar 3.

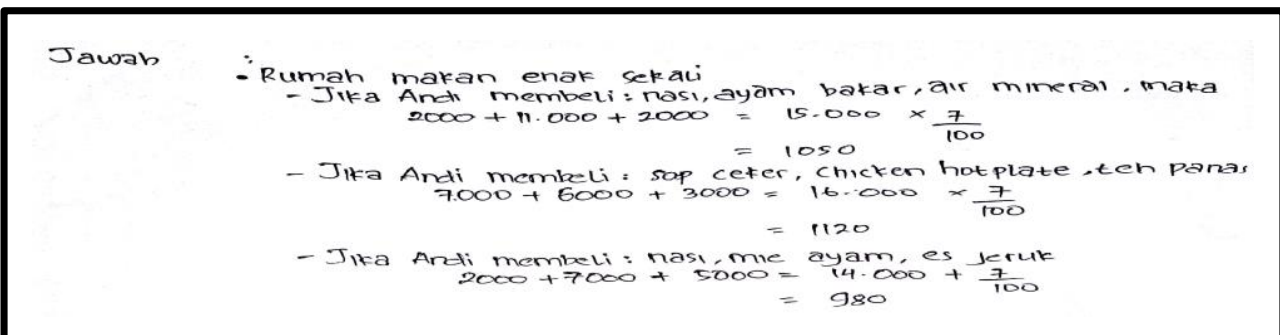

Gambar 3. Jawaban Subjek Menerapkan Konsep Secara Algoritma

Dari gambar 3 terlihat pada penulisan jawaban untuk menghitung harga yang paling murah dirumah makan enak sekali, terdapat satu jawaban subjek yang tidak berurutan sehingga untuk melihat berapa banyak diskon yang diberikan oleh rumah makan "enak sekali" kurang tertata rapi. Namun tidak mempengaruhi jawaban subjek selanjutnya karena subjek dapat menentukan dimana terdapat diskon yang paling murah dari kedua rumah makan. Untuk mengetahui mengapa subjek tidak menjawab secara berurutan, peneliti melakukan wawancara kepada subjek. Kutipan wawancara tersebut adalah sebagai berikut:

\section{$P$ : Dalam menentukan harga makanan dan minuman yang mendapat diskon di rumah makan enak sekali, mengapa penulisan jawabannya dibuat tidak berurutan? \\ $S$ : Menurut saya penulisan bagaimana jawabannya tidak berpengaruh, sehingga saya memulainya dengan harga Rp. 15.000, kemudian dilanjutkan harga $R p, 16.000$ dan harga $R p .14 .000$}

Dari kutipan wawancara tersebut diketahui bahwa subjek tidak secara berurutan menuliskan harga makanan dan minuman. Karena menurutnya itu tidak mempengaruhi jawabannya. Seharusnya subjek menuliskan jawabannya secara berurut, karena itu akan mempermudah dalam memperoleh hasil akhir. Siswa dapat mempresentasikan konsep dalam berbagai bentuk matematika, sebagaimana ditunjukkan pada Gambar 4.

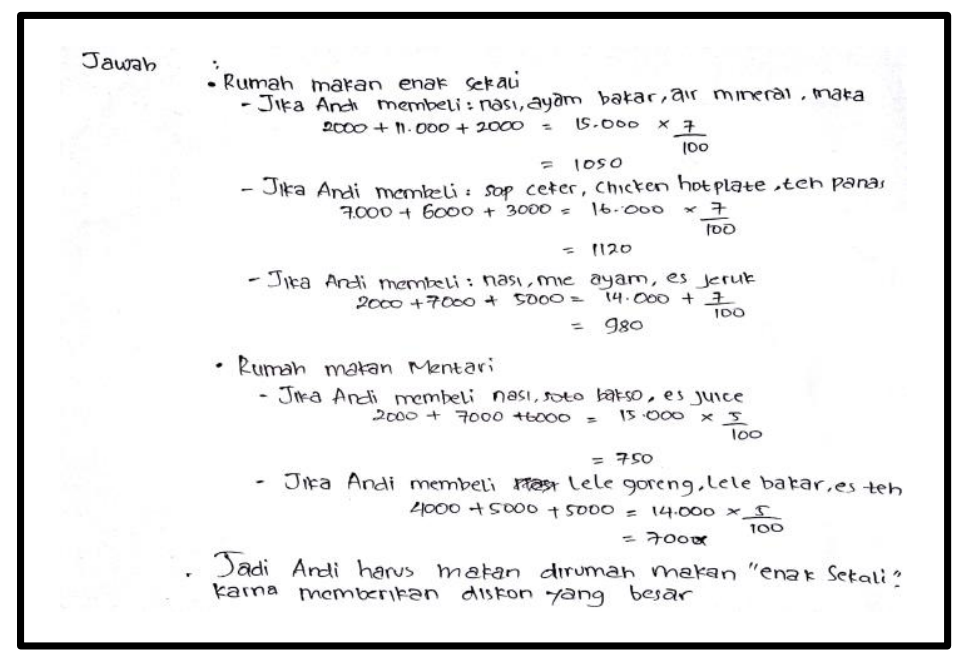

Gambar 4. Jawaban Subjek Mempresentasikan Konsep

Dari gambar 4 diketahui bahwa subjek kurang tepat dan jelas dalam mempresentasikan berbagai bentuk matematika. ini terlihat pada bagian akhir jawaban subjek, dimana subjek tidak menuliskan salah satu pertanyaan yang diminta soal yaitu menu apa yang harus dipilih Andi agar uangnya cukup. Namun, untuk menentukan di rumah makan yang mana Andi harus makan sudah tepat. 
Pada proses berpikir siswa berdasarkan pemahaman prosedural diketahui bahwa subjek menggunakan prosedur yang tepat. Dari Gambar 3 terlihat bahwa subjek telah memilih prosedur pemecahan masalah yang tepat, yaitu dengan menggunakan berbagai jawaban yang mungkin. Untuk menentukan harga yang paling murah dari kedua rumah makan, subjek menjawab dengan berbagai kemungkinan jawaban. Dalam menentukan harga di rumah makan enak sekali subjek menggunakan tiga kemungkinan jawaban. Jika harga dua makanan dan minuman yang dibeli sebesar Rp 15.000, maka Andi mendapat potongan harga sebesar Rp 1.050. Selanjutnya, jika Andi membeli dua makanan dan minuman dengan harga Rp 16.000 maka Andi mendapat potongan harga Rp 1.120 dan seterusnya.

Selanjutnya, subjek mengetahui tentang kapan dan bagaimana menggunakan prosedur tersebut, terlihat bahwa subjek telah memahami strategi pemecahan masalah yang telah dipilihnya. Namun, dari satu pertanyaan yang belum dijawab siswa diketahui bahwa siswa belum merencanakan pemecahan masalah dengan matang. Untuk mengetahui alasan subjek tidak menjawab satu soal yang diberikan, peneliti melakukan wawancara. Kutipan wawancara tersebut adalah sebagai berikut:

\section{$P$ : Mengapa untuk pertanyaan menu apa yang harus dipilih tidak dijawab? \\ $S$ : Karena saya bingung, ketika telah menentukan harga di rumah makan yang mana yang paling murah, maka kita bebas memilih menu apa saja}

Dari kutipan wawancara tersebut terlihat subjek belum merencanakan pemecahan masalah secara matang. Pada indikator ini, subjek telah menerapkan pemecahan masalah yang dipilihnya, namun dikarenakan perencanaan pemecahan masalah yang digunakan oleh subjek belum matang menyebabkan pengaplikasian strategi pemecahan masalah yang dipilih belum tepat. Untuk mengetahui alasan siswa mengaplikasikan langkah-langkah yang dipilih dalam memecahkan soal peneliti melakukan wawancara. Kutipan wawancara tersebut adalah sebagai berikut.

\section{$P$ : Bagaimana kamu yakin menu di rumah makan enak sekali yang paling murah? \\ $S$ : Dari beberapa makanan dan minuman yang saya pilih di setiap rumah makan kemudian saya menentukan harga diskonnya. Ternyata rumah makan enak sekali memberikan diskon yang besar jika harga makanan yang kita beli semakin mahal.}

Berdasarkan kutipan wawancara di atas didapatkan bahwa siswa telah yakin dengan jawaban yang diperolehnya. Keyakinan diperlukan ketika siswa menyelesaikan masalah. Dari ketiga indikator pemahaman prosedural di atas diketahui bahwa subjek telah dapat memilih strategi pemecahan masalah dengan baik, namun dikarenakan adanya satu pertanyaan yang tidak dijawab mengakibatkan dalam menggunakan "kapan dan bagaimana" strategi pemecahan masalah serta pengaplikasian strategi subjek kurang tepat.

\section{PEMBAHASAN}

Proses berpikir siswa dalam menyelesaikan soal Higher Order Thinking Skills berdasarkan pemahaman konseptual dan prosedural adalah subjek telah memenuh indikator pertama pemahaman konseptual yaitu subjek telah dapat menuliskan kembali konsep yang telah dipelajari dengan baik. Artinya penafsiran dan penalaran subjek akan soal yang diberikan telah sesuai dengan tujuan dari soal yang diberikan. Cara subjek membaca soal sangatlah penting, dengan membaca soal secara baik maka subjek akan dapat memahami maksud soal. Menurut (Yudiani, Marhaeni, \& Sutama, 2014) membaca pada hakekatnya merupakan kegiatan membuat perkiraan, mengoneksikan, membuat rencana penyelesaian masalah. Dengan membaca saja belum cukup untuk menyelesaikan masalah. Dibutuhkan penalaran dan penafsiran tentang apa yang dibaca.

Berdasarkan hasil jawaban dan wawancara terhadap siswa diketahui bahwa siswa telah memenuhi indikator pemahaman konseptual yang kedua yaitu dapat menerapkan konsep secara berurutan. Namun, jawaban siswa tidak ditulis secara berurutan. Walaupun pada akhirnya siswa dapat menjawab soal dengan benar, namun dalam matematika urutan dalam menyelesaikan soal itu sangat penting. Hal ini dipertegas oleh (Herper, 2007) yang menyatakan bahwa dalam menyelesaikan masalah matematika diperlukan rencana dan perhitungan yang matang sehingga keberurutan langkah demi langkah dalam pengerjaan soal matematika sangat diperlukan.

Subjek belum memenuhi indikator mempresentasikan konsep. Ditinjau dari hasil tes dan wawancara diketahui bahwa subjek tidak menjawab satu pertanyaan yang ada pada soal. Hal ini bertolak belakang dengan salah satu indikator pemahaman konseptual yang dikemukakan oleh (Claudia, 2017) yaitu mempresentasikan konsep dalam berbagai bentuk matematika. Penyajian konsep dilakukan secara berurut dan sistematis. Dari beberapa indikator yang telah diterapkan untuk melihat pemahaman konseptual siswa ternyata subjek masih belum memenuhi pada indikator ketiga. Subjek tepat memenuhi indikator pemahaman konsep yang pertama dan pada indikator pemahaman konsep yang kedua kurang tepat.

Pada pemahaman prosedural subjek telah memenuhi indikator pertama yaitu memilih prosedur yang sesuai dalam menyelesaikan masalah yang dilihat dari jawaban siswa. Menurut Fitriyani dan Suhendri (2008) kemampuan mengaplikasikan rencana yang telah dirancang merupakan bagian dari kemampuan menyelesaikan masalah. Subjek belum dapat memenuhi 
indikator kedua pemahaman prosedural yaitu mengetahui tentang kapan dan bagaimana prosedur digunakan. Subjek belum merencanakan pemecahan masalah secara baik. Langkah-langkah pemecahan masalah menurut (Polya, 1985) salah satunya yaitu merencanakan pemecahan. Dalam merancang penyelesaian subjek harus menyesuaikan pengalaman terdahulu yang memiliki kemiripan dengan permasalahan sekarang. Selanjutnya, barulah merancang strategi penyelesaian masalah. Siswa harus lebih berhati-hati lagi dalam merencanakan pemecahan masalah. Sehingga tidak ada pertanyaan yang belum dijawab dalam soal.

Subjek belum memenuhi indikator pemahaman prosedural yang ketiga menerapkan prosedur yang telah direncanakan. Hal ini dikarenakan siswa tidak merancang strategi pemecahan masalah dengan baik. Namun, subjek yakin dengan jawaban yang telah diperolehnya. Namun, keyakinan itu juga harus disertai dengan pembuktian dan teori-teori. Menurut Nugroho (2018) pengambilan keputusan terhadap proses atau hasil didasarkan pada seperangkat kriteria yang telah ditentukan. Kegiatan siswa dalam mengaplikasikan langkah-langkah yang dipilih untuk merencanakan masalah harus didukung oleh teori yang ada.

\section{SIMPULAN}

Proses berpikir siswa dalam menyelesaikan masalah Higher Order Thinking Skills berdasarkan pemahaman konseptual dan prosedural adalah berdasarkan pemahaman konseptual subjek belum memenuhi indikator mempresentasikan konsep, tetapi memenuhi indikator menuliskan konsep yang telah dipelajari dan menerapkan konsep secara terstruktur. Untuk proses berpikir siswa berdasarkan pemahaman prosedural subjek tepat memenuhi indikator memilih prosedur yang tepat dalam menyelesaikan masalah, namun subjek kurang tepat memenuhi indikator mengetahui kapan dan bagaimana prosedur digunakan dan menerapkan prosedur yang telah direncanakan.

Dalam penelitian ini siswa sulit untuk mempresentasikan konsep matematika dalam berbagai bentuk. Bagi guru sebaiknya melatih siswa dalam mempresentasikan konsep matematika, misalnya dengan cara pemberian soal latihan. Dalam penelitian ini, peneliti menggunakan soal Higher Order Thinking Skills untuk melihat proses berpikir siswa berdasarkan pemahaman konseptual dan prosedural. Bagi pembaca yang tertarik dengan masalah ini dapat memilih menggunakan instrumen soal yang lain, misalnya soal open ended.

\section{DAFTAR RUJUKAN}

Bakar, N. B., \& Bakry. (2015). The Process of Thinking among Junior High School Students in Solving HOTS Question. International Journal of Evaluation and Research in Education, 4(3), 138-45.

Claudia, L. F. (2017). Pemahaman Konseptual dan Keterampilan Prosedural Siswa Kelas VIII Melalui Media Flash Player. Prosiding SI MaNIs (Seminar Nasional Integrasi Matematika dan Nilai Islami), 1(1), 26-31.

Creswell, J. W. (2010). Research Design Pendekatan Kualitatif, Kuantitatif, dan Mixed Method.

Fitriyani., \& Suhendri, H. (2008). Pengaruh Metode Resitasi terhadap Kemampuan Pemahaman Konsep Matematika Siswa. Prosiding Diskusi Panel Nasional Pendidikan Matematika. Fakultas Teknik, Matematika, dan Ilmu Pengetahuan Alam Universitas Indraprasta PGRI, 150-159.

Haghverdi, M., \& Wiest, L. R. (2016). The Effect of Contextual and Conceptual Rewording on Mathematical Problem-Solving Performance. The Mathematics Educator, 25(1), 56-73.

Herper, J. L. (2007). The Uses of Computer Algebra Systems in a Procedural Algebra Course to Facilitate a Framework Dor Procedural Inderstanding. https://scholarworks.montana.edu/xmlui/handle/1/1433.

Krathwohl, D. R. (2002). A Revision of Bloom'S Taxonomy, 41(4), 212-19.

Laswadi., Kusumah, Y. S., Darwis, S., Afgani, J. D. (2016). Developing Conceptual Understanding and Procedural Fluency for Junior High School Students through Model-Facilitated Learning (MFL). European Journal of Science and Mathematics Education, 4(1), 67-74.

Nugroho, R. H. (2018). Higher Order Thinking Skills. Jakarta: Gramedia Widyasrana Indonesia.

Porter, M. K., \& Masingila, J. O. (2009). Examining the Effects of Writing on Conceptual and Procedural. Educational Studies, 42(2), 165-77. DOI https://doi.org/10.1023/A:1004166811047

Sa'dijah, C., Qohar, A., \& Anwar, L. (2017). Asesmen Dalam Pembelajaran Matematika yang Mendukung Sikap, Pengetahuan, dan Keterampilan Matematika. Universitas Negeri Malang.

Saido, G. M., Siraj, S., Nordin, A. B. B., \& Amedy, O. S. A. (2015). Higher Order Thinking Skills Among Secondary School Students in Science Learning. The Malaysian Online Journal of Educational Science, 3(3), 13-20.

Siregar, N. R. (2017). Persepsi Siswa pada Pelajaran Matematika: Studi Pendahuluan pada Siswa yang Menyenangi Game. Prosiding Temu Ilmiah X Ikatan Psikologi Perkembangan Indonesia: 224-32.

Star, Jon R. (2016). Reconceptualizing Procedural Knowledge. Journal for Research in Mathematics Education, 36(5), 404411.

Tanujaya, B., Mumu, Jeinne., \& Margono, G. (2017). The Relationship between Higher Order Thinking Skills and Academic Performance of Student in Mathematics Instruction. International Education Studies, 10(11), 78-85. DOI:10.5539/ies.v10n11p78. 
Teimourtash, M. \& YazdaniMoghaddam, M. (2017). On the Plausibility of Bloom's Higher Order Thinking Strategies on Learner Autonomy: The Paradigm Shift. Asian-Pacific Journal of Second and Foreign Language Education, $2(1), 14$. https://doi.org/10.1186/s40862-017-0037-8

Thompson, T. (2008). Mathematics Teachers' Interpretation of Higher-Order Thinking in Bloom Taxonomy. International Electronic Journal of Mathematics Education, 3(2).

Walle, J. A. (2008). Sekolah Dasar dan Menengah Matematika Pengembangan Pengajaran. Jakarta: Erlangga.

Winarni., Setyo, E., \& Harmini, S. (2016). Matematika untuk PGSD. Jakarta: PT. Remaja Rosdakarya. 